\title{
Nakládání s komunálním odpadem ve světle nových předpisů
}

\section{DAGMAR VOLOŠINOVÁ, ROBERT KOŘÍNEK, JIŘí KUČERA}

\author{
Klíčová slova: odpad - komunální odpad - nakládání - legislativa - oběhové hospodářství
}

\section{SOUHRN}

Moderní služby obce v oblasti nakládání s pevným odpadem obvykle zahrnuji úklid a čištění veřejných prostor, sběr, přepravu, recyklaci a odstranění vzniklých odpadů. Služby nakládání s pevným odpadem patří mezi nejnákladnějši a nejkomplikovanější ze všech obecních systémů prací pro veřejnost. Současně to také může být nejméně oceněnou komunální službou. Zásobování vodou, elektřinou, likvidace požárů a policejní ochrana uspokojuje zásadně a okamžitě denní potřeby obyvatel a podniků, a proto je těmto službám dána mnohem vyšší priorita ze strany komunity a jejího vedení. Služby v oblasti nakládání s odpady jsou obvykle jednou z nejméně „voňavých“ veřejných služeb, ale jejich bezchybná funkčnost a efektivnost mají rozsáhlé dopady. K zajištění udržitelnosti a jednotnosti postupu nakládání s odpady slouží právní předpisy. Předpisy řídící odpadové hospodářství obcí České republiky byly v letošním roce po dlouhé době aktualizovány a k dnešnímu dni je účinný zákon č. 541/2020 Sb., o odpadech, a vyhláška č. 8/2021 Sb., Katalog odpadů. Druhý prováděcí předpis, vyhláška o nakládání s odpady, je momentálně v legislativní radě vlády. Následující článek popisuje, jaké změny pro odpadové hospodářství obcí tyto předpisy přinášejí a jak se Ize na ně připravit.

\section{ÚVOD}

Obec je základní územní samosprávné společenství občanů [1] pečující o všestranný rozvoj svého území a o potřeby svých obyvatel. Současně při plnění svých úkolů chrání veřejný zájem, kterým je i dodržování principů oběhového hospodářství.

Odpady jsou všechny předměty nebo látky, jichž se držitel zbavuje, má v úmyslu se zbavit nebo je ze zákona povinen se jich zbavit. Odpady představují neefektivní využívání surovin, a tedy ztrátu zdrojů. Odpady navíc mohou obsahovat nebezpečné látky nebo mít nebezpečné vlastnosti a následně mohou znečištovat životní prostředí a způsobovat zdravotní rizika. Také procesy využití a zpracování odpadu mohou produkovat emise. V současné době je snižování odpadu primárním cílem nakládání s odpady. Úkoly nakládání s pevným odpadem představují složité technické výzvy. Rovněž znamenají širokou škálu administrativních, ekonomických a sociálních problémů, které je třeba zvládnout a vyřešit.

Správné nakládání s odpady má zásadní význam pro účinné využívání zdrojů a rozvoj udržitelného environmentálního plánování. Nejdůležitějším prvkem systému nakládání s odpady je jejich třídění. Většina recyklovaných materiálů z celkového toku komunálních odpadů se nachází v domácnostech a jejich odpadech.
Komplexní úpravu problematiky odpadového hospodářství od předcházení vzniku odpadu pres výčet způsobů nakládání s ním až po jeho odstranění, a to vše $v$ souladu $s$ hierarchií nakládání s odpady a environmentálně bezpečně, přinesly v letošním roce nové právní předpisy. Konkrétně se jedná o zákon č. 541/2020 Sb., o odpadech, (dále jen ZoO) a dva prováděcí předpisy. Jde o vyhlášku č. 8/2020 Sb., Katalog odpadů, a vyhlášku o nakládání s odpady (dále jen VNO), která dosud není vydána. VNO shrnuje problematiky, jež v minulosti upravovala řada vyhlášek (č. 382/2001 Sb., 383/2001 Sb., 384/2001 Sb., 294/2005 Sb., 321/2008 Sb., 341/2008 Sb., 374/2008 Sb., 387/2016 Sb. a 437/2016 Sb.). Vyhláška si klade za cíl posílit ochranu životního prostředí podrobnější a přehlednější právní úpravou zajištující lepší kontrolu dodržování veškerých povinností při nakládání s odpady a lepší vymahatelnost práva. Výčet povinností obcí při nakládání s komunálními odpady uvádíme v článku spolu s možností jejich plnění.

Komunálním odpadem (dále jen $\mathrm{KO}$ ) rozumíme směsný a tříděný odpad z domácností, zejména papír a lepenku, sklo, kovy, plasty, biologický odpad, dřevo, textil, obaly, odpadní elektrická a elektronická zařízení, odpadní baterie a akumulátory, a objemný odpad, zejména matrace a nábytek. Do KO také zařazujeme odpad směsný a tříděný z jiných zdrojů, pokud je co do povahy a složení podobný odpadu z domácností. Povinností obce je zajistit, aby občan měl možnost veškerý $\mathrm{KO}$, který vyprodukuje na území obce, rádně uložit na místo určené obcí. To znamená umožnit odevzdat vyprodukovaný odpad na obecně závaznou vyhláškou vymezených místech, ve sběrných dvorech nebo v př́padě nedostatečné kapacity i zorganizovat sběr objemného odpadu. $V$ jaké míre, to zákon nestanoví, obec vychází ze svých zvyklostí a potřeb. Další možností je po domluvě využívat kapacitu sběrného dvora sousedních obcí. Stále však platí, že přednostně je využíván systém zpětného odběru pro pneumatiky, elektrozařizení, baterie, tonery použité v domácnostech či domácí kompostování bioodpadu. Dojde tak nejen k snížení objemu komunálních odpadů, ale i k získání znovu využitelných materiálů.

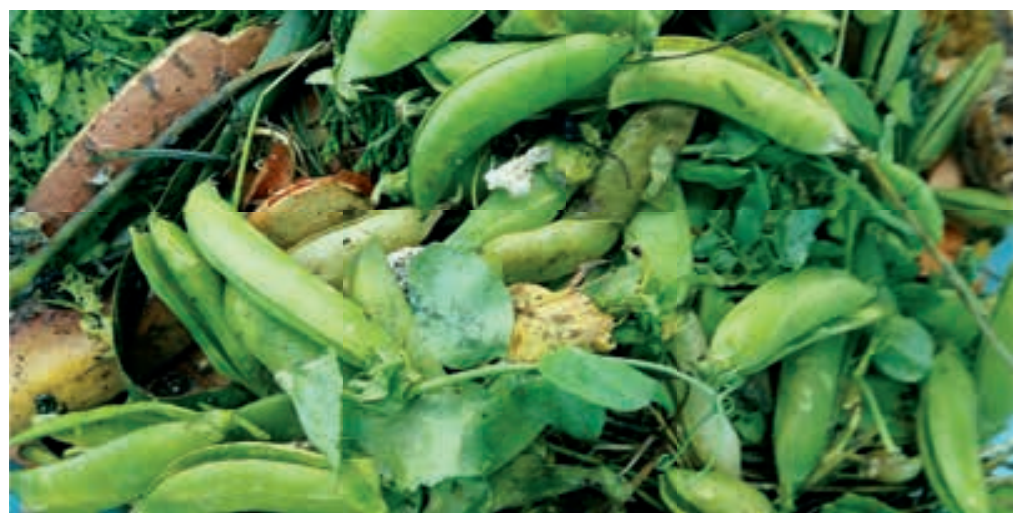




\section{POVINNOSTI OBCÍ PŘI NAKLÁDÁNÍ S KOMUNÁLNÍMI ODPADY}

Zajištění soustřed’ování KO bylo plně převzato z vyhlášky č. 321/2014 Sb. Obec musí zajistit místa pro oddělené soustřed’ování odpadů po celý rok. Výjimkou jsou nebezpečné odpady, u těch je dostačující zajistit místo soustředění pouze dvakrát ročně. Pro eliminaci ohrožení životního prostředí a lidského zdraví při manipulaci s tímto druhem odpadů je nutné předání provést za asistence obsluhy.

Nastavení obecního systému nakládání s komunálními odpady provádějí obce pomocí obecně závazných vyhlášek, které by měly být v průběhu tohoto roku aktualizovány. Ministerstvo vnitra spolu s Ministerstvem životního prostředí připravilo metodický návod [2-4] k nastavení obecního systému nakládání $\mathrm{S} K \mathrm{KO}$ a vypracování obecně závazné vyhlášky.

Podrobnosti, jakým způsobem musejí obce zajistit soustřed’ování KO, jsou uvedeny níže:

\section{A. Oddělené soustřed’ování}

Obce mají povinnost určit místa pro oddělené soustřed’ování recyklovatelných složek KO (\$ 59 odst. 2 ZoO). Odděleně soustřed’ovaný papír, plast, sklo a kov mohou být soustřed’ovány společně, ale nesmějí být príčinou snižení možnosti využivat tyto odpady v souladu s hierarchií odpadového hospodářství (viz § 30 ZoO). Kapacitami kontejnerů a množstvím svozů Ize zohlednit sezonní změny. Obce mají povinnost dosahovat vysokých cílů třídění KO. Konkrétně je nastaveno $60 \%$ odděleně soustřed’ovaných složek do roku $2025,65 \%$ do roku 2030 a $70 \%$ do roku 2035. Toho mohou dosahovat bud" následným tříděním směsného KO na lince, anebo podporou třídění složek $\mathrm{KO}$ prímo u producentů, respektive občanů. Je povinností zavést třídění minimálně pro papír, sklo, kov, plasty, bioodpad, oleje a tuky a do roku 2025 i textilu. Od roku 2023 při organizování sběru objemného odpadu je povinností jej před uložením na skládku také roztř́ídit na základní složky, jako je plast, papír a dřevo, pokud nebyl při soustřed’ování oddělován alespoň kov, plast a biologický odpad velkých rozměrů.

B. Komunitní kompostárna

Nakládání s biologicky rozložitelným odpadem je ve VNO ošetřeno mnohem podrobněji než v dřivější vyhlášce č. 341/2008 Sb. V tabulce č. 1 a 2 př́lohy č. 24 VNO jsou vymezeny biologicky rozložitelné odpady, které lze zpracovávat biologickými procesy ve vymezených zařízeních (dle kapacity kompostárny dělíme na velká a malá zařizení). Podle ZoO musejí být tyto odpady přednostně zpracovány právě biologickými procesy. Pro zefektivnění procesu kompostování a zlepšení kvalitativních vlastností výstupu mohou být do těchto procesů přidávány zeminy, písky a látky s prokazatelně zlepšujícími účinky.

Nově je definován termín zakládka jako základní technologický pojem pro stanovení správného postupu zpracování rostlinných zbytků. Zakládka je směs biologických odpadů nebo rostlinných zbytků z údržby zeleně, zahrad a domácností a dalších složek, složených podle stanovené skladby (receptury) ve stejném termínu do jedné či více hromad tak, aby byl zajištěn aerobní proces (\$ 2 písm. g) VNO). Zakládka je také základní jednotkou, ke které se vede evidence o složení kompostovaných materiálů, dále o zjištěných parametrech kompostovacího procesu (teplota, vlhkost), následně provedených opatřeních (překopávka, zavlažení) a o délce kompostovacího procesu a kvalitě výstupu kompostu.

Pro nakládání s vytříděným bioodpadem si může obec nebo sdružení obcí zřídit komunitní kompostárnu. Ohlášení provozu komunitní kompostárny je součástí ročního hlášení obce, na jejímž území je komunitní kompostárna provozována. Komunitní kompostování, jež bylo dosud ošetřeno pouze metodickým pokynem, je nyní upraveno v §54 VNO. Komunitní kompostárna je dle ZoO považována za předcházení odpadů, ale z důvodu shodného procesu kompostování budou od roku 2025 požadavky na vybavení komunitní kompostárny a kompostovacího procesu shodné s požadavky na kompostárny odpadové. Provozovatel komunitní kompostárny má povinnost vést evidenci, jaké množství rostlinných zbytků a od jaké obce do kompostárny převzal. Rozsah evidence je uveden v př́loze č. 33 VNO. Od počátku roku 2022 již bude provozovatel komunitní kompostárny muset navíc plnit povinnosti vedení provozního deníku v předepsané formě dle prílohy č. 32 VNO. Hlášení o množství zpracovaných bioodpadů v roce 2021 bude muset zaslat do 28. února 2022.

\section{Sběrné dvory}

Dalším zpưsobem zvýšení využitelného podílu KO je provozování sběrných dvorů, a to opět bud' samotnou obcí, nebo sdružením obcí. Provozování současných zařízení lze i nadále rídit dle § 14 odst. 1 zákona č. 185/2001 Sb., ještě po dobu dvou let. To znamená, že nejdéle 6 měsíců pred uplynutím dvouleté Ihưty je nutné zažádat o vydání povolení dle nového ZoO. Současně je nutné provést revizi povolení provozu zařizení včetně provozních rádů ve Ihůtě 6 let ode dne nabytí právní moci povolení provozu zařízení. V jiném prípadě nelze toto zařízení dále provozovat. Pokud sběrné dvory přebírají odpad v rámci obecního systému a neposkytují za převzetí odpadu úplatu, nemusejí u kovového odpadu vést podrobnou evidenci o prijiatých odpadech ani o předávající osobě, čímž se vyhnou povinnosti instalace systému (§ 19 ZoO).

\section{D. Školní sběr}

Od 1. ledna 2021 může škola prebírat od žáků a studentů pouze odpady papíru, plastů a kovů z domácností. Pưvodcem odpadů sebraných ve školách během školního sběru je obec. V rámci hlášení za rok 2021 obec zahrne tyto odpady jako vlastní produkci (A00). Informaci o množství předá škola obci zasláním vyplněného formuláre stanoveného v príloze č. 3 VNO. Školy museji od začátku roku informovat osobu, již odpad predávají, o tom, že pưvodcem odpadu, který je uváděn do evidence, je obec.

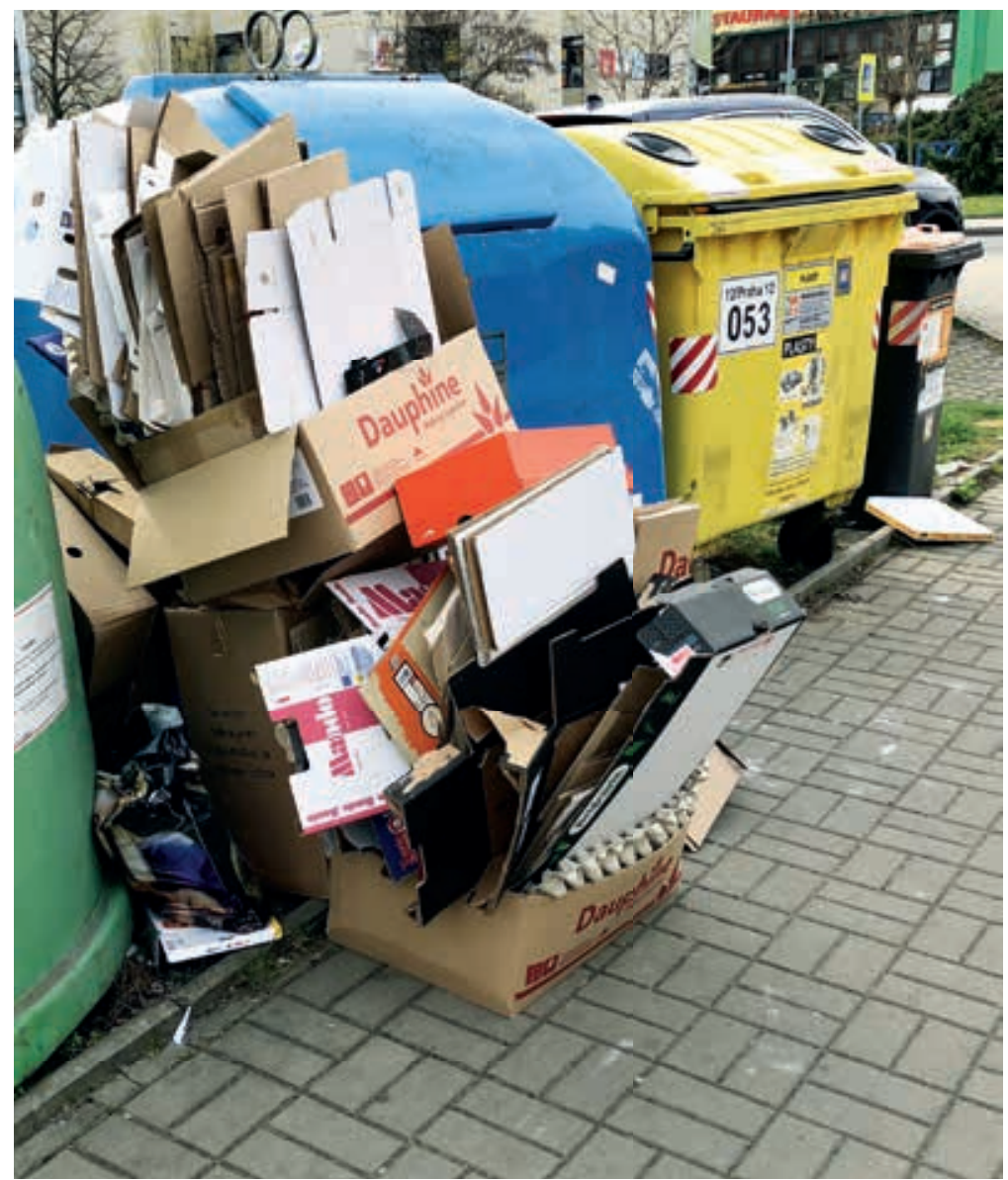


E. Skládky

Jako nejméně vhodný způsob nakládání s odpady je hodnoceno skládkování. VNO obsahuje seznamy odpadů, jež je striktně zakázáno na skládky ukládat. V príloze č. 4 v bodě C se jedná o nebezpečný odpad, který bude od roku 2022 technicky vhodnější spálit ve spalovnách nebezpečného odpadu, a v bodě E o ostatní odpady, pro něž existují recyklační technologie, které bude zakázáno skládkovat od roku 2030. To znamená, že za odpady uvedené $\checkmark$ bodě E se hradí vyšší skládkovací poplatky, a to již od roku 2022. Do konce roku 2021 je ukládání odpadů v bodě E zpoplatněno jako zbytkový odpad. VNO také vyžaduje v základním popisu odpadu odůvodnění, proč s odpadem nelze nakládat jiným způsobem, který je v souladu s hierarchií způsobů nakládání s odpady (§ 24 a př́loha č. 12 VNO). Dosud postačilo čestné prohlášení, ale dle VNO je nezbytné, aby předávající osoba dostatečnými argumenty odůvodnila, proč uložení odpadu na skládku je tím nejlepším řešením. Důvod, že jiný způsob nakládání je ekonomicky náročnější, není dostatečný.

ZoO ukládá původci odpadu jednoznačnou povinnost předávat odpady prrímo do zařízení (\$15 ZoO). Není možné, aby provozovatel převzal do zařízen odpady, aniž by provedl jejich přejímku. V prípadě provedení kompletní přejímky může provozovatel zařizení príijmout odpady do vlastnictví při zahájení přepravy odpadu do jeho zařizení. Nově tak nesmějí být v evidenci odpadového zařízení uvedeny žádné odpady, které tímto zařizením fyzicky neprošly. Z tohoto důvodu má ZoO nové nástroje "zprostredkovatele" a „obchodníka”.

\section{F. Zprostředkovate}

Zprostředkovatel může uzavřít smlouvu s původcem odpadu, v níž původce zmocní zprostředkovatele $k$ tomu, aby jeho jménem zajistil předání odpadu do zařizení určeného pro nakládání s odpady a také smlouvu s provozovatelem zařízení, na jejímž základě provozovatel príime odpady od klientů zprostředkovatele (původců odpadů) do takového zařizení.

\section{G. Obchodník s odpady}

Podle ZoO může s odpady obchodovat právnická osoba nebo podnikající fyzická osoba, jež provádí nákup a prodej odpadů na vlastní odpovědnost a která zároveň pro tuto činnost získá povolení krajského úřadu (\$ 11 odst. 1 písm. c) a p) a $\$ 26$ odst. 1 ZoO).

Zásadní rozdíl mezi zprostředkovatelem a obchodníkem spočivá v tom, že zprostředkovatel se prevzetím odpadu nestává jeho vlastníkem, zatímco obchodník ano (§ 44 odst. 2 a $\S 45$ odst. 3 ZoO).

\section{H. Černé skládky}

Pokud se vyskytne odpad nezákonně soustředěný mimo zařízení určené k nakládání s odpady a není možné dohledat osobu, která je za tento odpad zodpovědná, jedná se o tzv. černou skládku. ZoO vychází z principu „vlastnictví zavazuje" a stanovuje postup pro zjištění osoby odpovědné za nelegálně soustředěný odpad a pro zajištění rádného naložení s ním. Vlastník pozemku, na němž se „černá skládka“ nachází, má povinnost bezprostředně po zjištění tuto skutečnost nahlásit na obecní úřad. Pokud se nepodaři zjistit původce odpadu, obecní úřad vyzve vlastníka pozemku, na kterém se "černá skládka“ nachází, k jejímu odklizení. Pokud vlastník pozemku odpad neodklidí, přestože byl k tomu vyzván, obecní úřad může vstoupit na dotčený pozemek a odpad odklidit (§ 14 odst. 5 a odst. 6 ZoO) a náklady následně vymáhat na vlastníkovi pozemku.

\section{Evidence}

Průběžná evidence za rok 2021 a 2022 se vede dle původní, zrušené vyhlášky č. 383/2001 Sb., včetně použitých kódů nakládání. Průběžná evidence odpadů se vede při každém předání nebo převzetí odpadu či naplnění prostředku pro soustřed’ování odpadu, při každém provedení úpravy, využití nebo odstranění odpadu, při přeshraniční prepravě, dovozu nebo vývozu. Roční hlášení

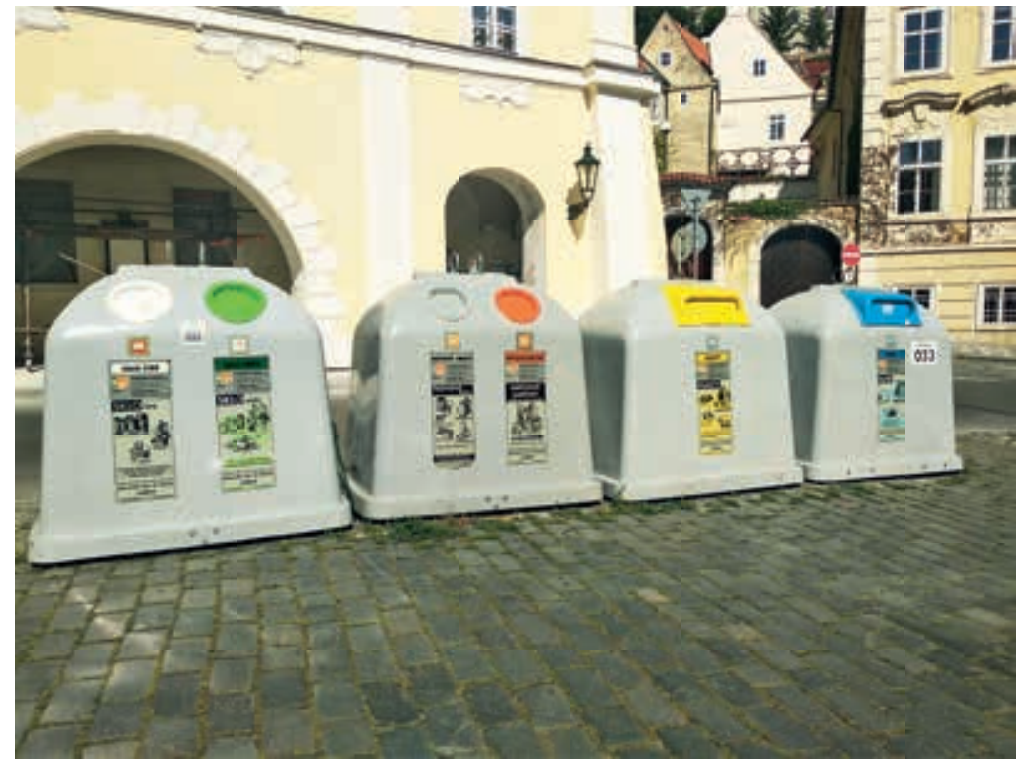

(§ 27 VNO) o obecním systému nakládání s odpady je mnohem podrobnější. Byly doplněny list 6 Údaje o obsahu perzistentních organických látek podle prílohy IV nařizení č. (EU) 2019/1021, list 7 Údaje o příjmu zařízení obsahujících PCB a odpadů PCB a list 8 Údaje o vstupech a výstupech ze zařizení k mechanické úpravě, třídění, dotrídění (třídicí, dotřidovací linka, mechanicko-biologická úprava apod.). Hlášení v roce 2022 je nutné zaslat do 28. února 2022 a nově jej musí podat původce odpadů, který v roce 2021 vyprodukoval minimálně 600 kg nebezpečných odpadů a nejméně 100 tun odpadů ostatních. Odpady Ize podle ZoO predávat pouze do zařizení, není možné, aby provozovatel převzal odpady, aniž by provedl přejímku odpadu a převzal je do zařízení. Přejímku odpadu, tj. převzetí do vlastnictví, Ize provést při zahájení přepravy odpadu do zařizení provozovatele.

Pro financování obecního systému nakládání s odpady jsou stanoveny poplatky a jejich výše.

\section{J. Poplatek za KO}

Nový ZoO vyšel ve Sbírce zákonů 31. prosince 2020 a nabyl účinnosti 1. ledna 2021. I kdyby některá obec chtěla zavést zpoplatnění podle změněných předpisů již v roce 2021, nebylo by to z procesních dưvodů možné (obec nemůže vydat obecně závaznou vyhlášku podle ještě nevydaného právního předpisu a pro svolání zastupitelstva obce je stanovena lhůta nejméně 7 dní předem). Nezbylo tedy než vyjít z § 156 ZoO a v roce 2021 v obcích zachovat dosavadní, dřive zavedený systém zpoplatnění odpadů. Protože poplatek je stanoven na rok, fakticky ho Ize měnit jen k 1. lednu každého roku. Od 1. ledna 2021 už mohou obce vybírat jen místní poplatek za komunální odpad, jak je definován v zákoně č. 565/1990 Sb., o místních poplatcích, ve znění pozdějších předpisů (dále jen ZoP). Místním poplatkem za komunální odpad je poplatek za obecní systém odpadového hospodářství a poplatek za odkládání KO z nemovité věci. Obec může zavést pro poplatkové období pouze jeden z poplatků. Možnost uzavření smlouvy, která byla dosud dána zrušeným zákonem o odpadech, je zcela vypuštěna.

Předmětem poplatku za obecní systém odpadového hospodářství je skutečnost, že občan-poplatník má v obci možnost využívat obecní systém nakládání s odpadem, a maximální výše sazby poplatku je 1200 Kč (§ 10h ZoP). Poplatek za odkládání komunálního odpadu z nemovité věci je založen na principu „znečištovatel platí, tedy na skutečném množství vyprodukovaného odpadu. ZoP obcím umožňuje zvolit si jednu ze tři možností stanovení základu poplatku (§ 10k ZoP) v návaznosti na systému svozu KO, který je $\checkmark$ obci zaveden. Obec může zpoplatnit bud' hmotnost odpadu odloženého z nemovité věci v kilogramech připadajícího na poplatníka, objem odpadu 
odloženého z nemovité věci v litrech připadajícího na poplatníka, nebo kapacitu soustřed’ovacích prostředků pro nemovitou věc na odpad v litrech prípadající na poplatníka. Vybraný způsob zpoplatnění musí obec dodržovat po celý kalendáŕní rok.

ZoP vyjmenovává pět př́padů osvobození od poplatku (§10g ZoP), jako například pro osoby ve výkonu trestu, nezletilé osoby umístěné v dětských domovech nebo pro seniory žijící v domově pro seniory. Další osvobození či úlevy může obec stanovit v obecně závazné vyhlášce.

Obecně závazné vyhlášky o místním poplatku za komunální odpad musejí všechny obce vydat v průběhu roku 2021, jinak budou nuceny hradit provoz svého systému odpadového hospodárství pouze z vlastních zdrojů. Od 1. ledna 2022 nabývá účinnosti zákon č. 35/2021 Sb., o Sbírce právních předpisů územních samosprávných celků a některých správních úřadů, podle kterého právní předpisy obce (tedy i obecně závazné vyhlášky) nabývají platnosti až jejich zveřejněním ve Sbírce právních předpisů, nikoli vyvěšením na úřední desce obce, jako je tomu doposud. To se týká i prípadných změn obecně závazné vyhlášky o místním poplatku za komunální odpad. Obecně závazná vyhláška o místním poplatku za komunální odpad, jež byla nebo bude vydána v roce 2021, musí být zaslána ke zveřejnění ve Sbírce právních předpisů nejpozději do tři let od nabytí účinnosti zákona č. 35/2021 Sb., jinak pozbude platnosti.

K. Poplatek za ukládání odpadů na skládku

Poplatníkem poplatku za ukládání KO je od 1. ledna 2021 obec, pokud je vedena jako pưvodce ukládaného KO (§ 103 písm. b) ZoO). Odpady jsou zákonem ZoO z důvodu odlišné výše poplatku rozděleny do 5 kategorií (využitelné, zbytkové, nebezpečné, vybrané technologické a sanační, viz § 107 a př́loha č. 9 ZoO). Sazba za využitelné a zbytkové odpady je počínaje rokem 2021 navyšována až na hodnotu 1850 Kč v roce 2029. Aby nebyl nárůst poplatků tak razantní, byla zavedena tzv. tř́ící sleva, kdy napríklad v roce 2021 bude 200 kg skládkovaného odpadu na osobu zpoplatněno pouhými 500 Kč oproti 800 Kč

\section{Třídicí sleva}

Množství a poměr vyprodukovaných odpadů budou obce řešit jak z důvodu plnění povinných cílư, tak i z důvodu výše poplatku za ukládání odpadu na skládky. Obce mají za splnění zákonem stanovených předpokladů nárok na tzv. třídicí slevu (§ 157 ZoO). Až do konce roku 2029, tedy do začátku zákazu skládkování využitelného odpadu, mohou obce ukládat využitelný KO na skládku za snížený poplatek (viz výše bod k).

\section{ANALÝZA SLOŽENÍ ODPADU゚}

Obce jsou postaveny před nelehký úkol - vyhovět právním předpisům v oblasti sběru, třídění a zpracování odpadů, aniž by byly nuceny zvyšovat poplatky.

Aby bylo možné navrhnout odpovídající plán nakládání s KO, první krok spočívá v definici produkovaného odpadu a jeho složení. Jelikož tyto vzorce závisejí na několika sociálně-ekonomických faktorech, je vhodné je uspořádat předem. Navíc modely vzniku a složení odpadu se mohou lišit v rưzných částech obce a v průběhu času. Obecné údaje o počtu obyvatel a hospodářské činnosti živnostníků nejsou homogenní ani konstantní.

Analýza složení odpadu poskytuje informace o druzích a množstvích materiálů, které jsou v daném toku odpadu. Analýza umožňuje místním orgánům shromaždovat informace o rozsahu materiálů v jejich odpadním toku a také o množství každého z těchto materiálů a jejich relativních podílech v odpadu. Pokud se provádí v několika intervalech po dobu jednoho roku, může analýza také zdůraznit rozdíly ve složení odpadu v různých ročních obdobích.

Studie složení odpadu poskytuje informace, které Ize dále použít pro postupné ekonomické, politické a organizační rozhodování. Ve studiích složení odpadu je důležitým kritériem stanovení vhodných stratifikačních faktorů: typ zástavby, zdroj odpadu, socioekonomické postavení.
V současné době není stanoven žádný evropský standard pro analýzu složení směsného KO. Existují pouze doporučení některých organizací. Niže uvádíme nejčastěji využívané metody analýz v evropských státech $s$ vyspělým odpadovým hospodářstvím.

A. Metodika SWA-Tool - Solid Waste Analysis Tool je metodika vyvinutá v rámci projektu Evropské komise [5], jehož snahou bylo standardizovat postupy využívané při rozborech složení KO. Jak jsme uvedli výše, tato metodika se evropským standardem nestala. Metodika doporučuje analyzovat celý vzorek bez získávání podvzorku. Vzorek je získáván prímo ze sběrných nádob. Stratifikační faktory (např. typ zástavby, průměrné př́ijmy obyvatel, HDP na obyvatele nebo jiné statistické údaje) nejsou vyžadovány, ale jen doporučovány podle potřeb. Třídění vzorku probíhá kombinací manuálního a strojového do 13 hlavních kategorií a 35 podkategorií.

B. Metodiku MODECOM - Method of Characterization of the household waste vyvinul francouzský úrad pro energetiku a životní prostředí (ADEME) v roce 1998 [6]. Metoda je založena na manuálním vzorkování svozových vozů. Vzorek o hmotnosti 500 kg je rozdělen do 3 velikostních skupin (> 100 mm; 20-100 mm; < 20 mm). Hlavní třídění obsahuje 13 kategorií. Metoda neuvažuje chyby $\vee$ měření.

C. Argus Method - byla vyvinuta v Německu [7]. Využivá stratifikační faktor typ zástavby a třídí vzorek o hmotnosti do jedné tuny pomocí sít na tři velikostní frakce (> 40 mm; 10-40 mm; < 10 mm). Frakce nad 40 mm je zcela tříděna do 13 kategorií, ale prostřední frakce je trríděna jen částečně.

D. Netherlands AOO-IPA - nizozemská metoda institutu (National Institute of Public Health and Environmental Protection, RIVM), který ji použivá pravidelně k analýze složení směsného KO již od roku 1971 [8]. Metoda využívá kombinaci manuálního a strojového třídění (vibrační síta) na rozdělení vzorku do 3 velikostních kategorií. Hlavní úrovní trídění si získává 11 kategorií a až 100 dalších podkategorií.

E. Nordtest - finská metoda z roku 1995 [9]. Způsob sběru vzorků se odvíjí od konkrétního účelu vzorkování, a tím se od sebe značně liší at’ už místem sběru, nebo způsobem stratifikace (zejména socioekonomické faktory, např. věk, počet členů domácnosti). Reprezentativnost vzorků je dosahována dodržováním těchto zásad: za každou analyzovanou oblast se sbírá 100-200 vzorků, tj. 1-2,5 tuny. Podvzorek je získáván kvartací a zmrzlé vzorky je nutné rozmrazovat. Počet tříděných frakcí je stanovován individuálně podle konkrétních potřeb jednotlivých studií.

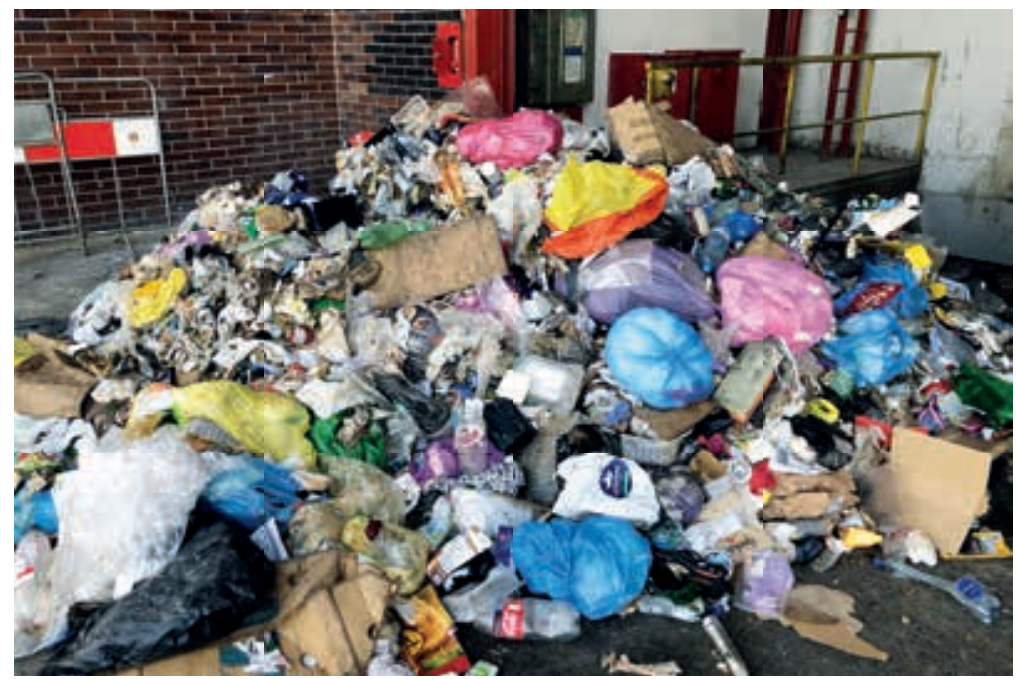


F. RVF - švédská metodika z roku 2005 [10], kterou pro švédské podmínky vytvorily University of Technology, NSR AB, The Swedish Sustainability Foundation a RVF. Sběr vzorků je prováděn svozovými auty. Vzorek je tříděn na 9 hlavních skupin a 22 podskupin.

G. SAEFL - švýcarská metoda z roku 2004 [11], jejímž cílem je analyzovat složení KO s využitím stratifikačních faktorů, jako jsou socioekonomické faktory, geografická lokalita, turismus, sezonnost, rozsah sběru separovaných složek KO. Analýza 16 tun směsného KO byla prováděna v oblasti Bernu z 33 obcí v období jara a podzimu. Vzorek byl získán svozovými auty a manuálně roztříděn na 18 frakcí.

H. Metodika Agentury pro životní prostředí Anglie a Walesu [12] - řeší zejména stratifikační parametry, které mají vliv na množství a složení odpadů. Sběr vzorku je prováděn ve sběrných místech a je analyzován celý bez získávání podvzorku. Manuálním tríděním je získáváno 13 hlavních kategorií a 37 podkategorií.

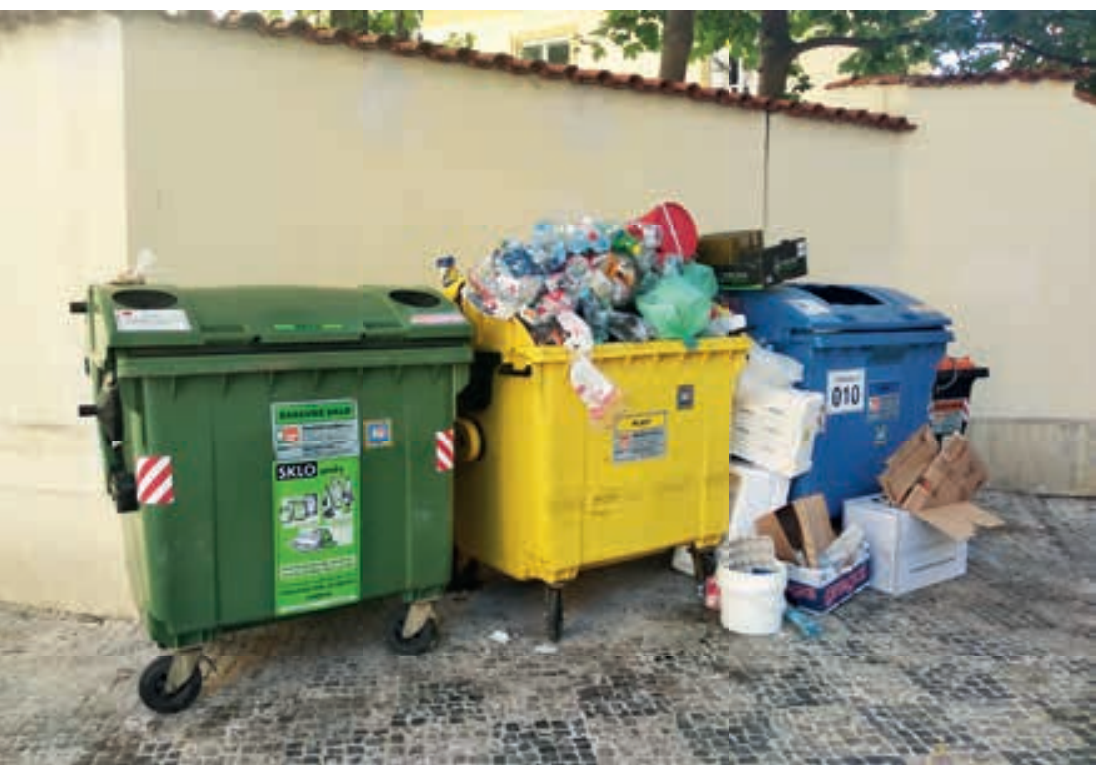

V České republice byla v rámci projektu SP/2f/132/08 - Výzkum vlastností komunálních odpadů a optimalizace jejich využivání [13] - vypracována metodika pro vzorkování, třídění a následný rozbor směsného KO. Sledovány byly tři typy zástaveb - sídlištní, venkovská a smíšená v měsíčních intervalech po dobu jednoho roku. Byl analyzován svoz jednoho automobilu (cca 6-8 tun). Kvartací zmenšený podvzorek o hmotnosti 200 kg byl manuálním rozborem pomocí sít roztříděn na tři frakce (> 40 mm; 8-40 mm; $<8$ mm). Zrnitostně největší frakce byla tříděna na 11 kategorií. Prostřední frakce je tříděna jen částečně. Při analýze jsou odebírány jednokilogramové laboratorní vzorky, jež jsou podrobeny fyzikálně-chemickým analýzám. Jsou zjištovány tyto ukazatele: vlhkost, spalné teplo, spalitelné látky, obsah fluoridů, chloridů, dusíku, síry a těžkých kovů, obsah organického uhlíku a dalších specifických látek, jako napríklad polychlorovaných bifenylů a polycyklických aromatických uhlovodíků.

Z důvodů časových, ale zejména finančních, jsou další metodiky rozborů směsných $\mathrm{KO}$ zjednodušené.

Např́klad společnost Odpadová Poradenská, s. r. O., [14] provádí rozbory pouze čtyři a jen ve dvou typech zástavby, aby pokryly stratifikaci ročních období a typ zástavby. Vzorek byl odebírán svozovým autem a manuálně pomocí jednoho síta roztříděn na kategorie odpadů shodných s metodikou projektu SP/2fl/132/08.
Firma EKO-KOM, a. s., [15] provádí rozbory ze tří typů zástavby - sídlištní, venkovské a vilové. Z každého typu zástavby zanalyzuje 200 kg směsného odpadu roztříděného na dvě frakce - nadsítná (> $40 \mathrm{~mm}$ ) a podsítná (< $40 \mathrm{~mm}$ ). Analýzy jsou zaměřeny pouze na látkové složení, zjištuje se obsah 9 kategorií. Fyzikálněchemické analýzy nejsou prováděny, nicméně průměrná vlhkost materiálu je k získaným datům dopočítávána.

VúV TGM v rámci řešení projektu CZ.07.1.02/0.0/0.0/16_040/0000379 Odpady a predcházení jejich vzniku - praktické postupy a činnosti při realizaci závazků Krajského Plánu odpadového hospodárství hlavního města Prahy [16] prováděl rozbor směsného KO, který vycházel z metodiky projektu SP/2fl/132/08. Po dobu dvou let byly analyzovány tři typy zástaveb - sídlištní, venkovská a centrální. Rozbory byly prováděny ve dvouměsíčních intervalech. Při každém bylo ze svozového auta odsypáno cca 1000 kg hlavního vzorku, který byl pak manuálně pomocí sít tříděn do čtyř zrnitostních frakcí (> 40 mm; 40 mm, 20 mm; < $8 \mathrm{~mm}$ ). Frakce nad $40 \mathrm{~mm}$ byla tříděna do 12 hlavních kategorií a 15 podkategorií. Ostatní frakce nebyly dotřid’ovány. Byly odebírány dvoukilogramové vzorky pro fyzikálně-chemické analýzy. Současně byl každý měsíc prováděn monitoring stratifikací, jako napríklad typy a efektivita využivání nádob pro tříděné složky KO a jejich čistota, donášková vzdálenost, sociodemografické údaje, občanská obslužnost.

Díky spolupráci se společností Pražské služby, a. s., jsme metodiku rozboru využili i pro rozbory směsného KO k vyhodnocení účinnosti pilotních projektů $\checkmark$ městských částech, kde bylo změněno spektrum nebo rozsah tříděných složek KO. V dalším prípadě, s ohledem na potřeby koncové technologie kompostování, byla metodika upravena tak, že analýza tříděného biologicky rozložitelného odpadu navíc zjištovala počet kusů nevhodných příměsí. U těchto typů vzorkování nebylo cílem vyhodnocovat či porovnávat složení směsných komunálních odpadů s jinými obcemi, nýbrž porovnat oblast pilotního projektu s oblastí, kde systém sběru KO zůstal nezměněn. Výsledky sloužily nejen k vyhodnocení úspěšnosti pilotních projektů, ale i k cílené motivaci obsluhovaných rezidentů.

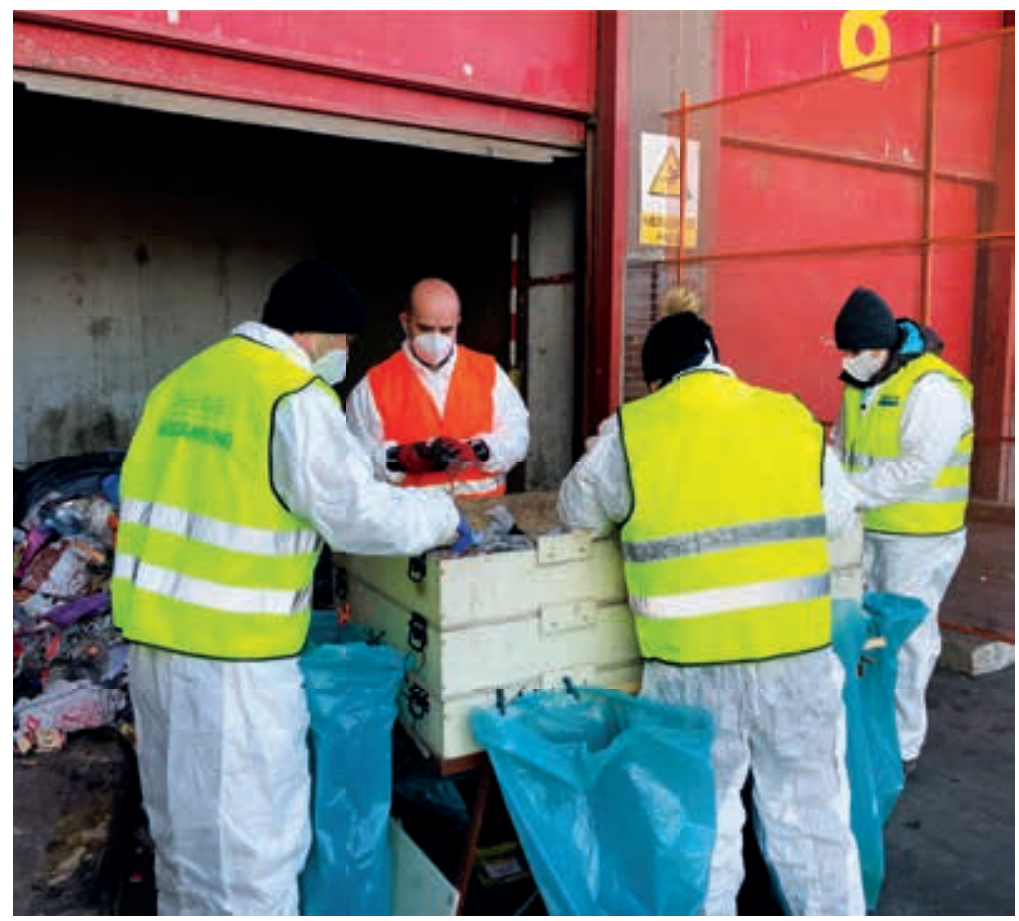

Obr. 1. Manuální rozbor směsného komunálního odpadu realizovaný pracovníky VúV TGM Fig. 1. Manual analysis of mixed municipal waste performed by WRI TGM employees 


\section{ZÁVĚR}

Systémy nakládání s komunálním odpadem se od letošního roku stávají složitějšími. Česká republika stejně jako většina evropských zemí je povinna splnit národní cíle v oblasti recyklace a využití zákazu skládkování. Strategie k dosažení cílů vyžaduje podrobné informace o množství vyprodukovaných odpadů a jejich složení. Ke sledování pokroku při plnění cílů a závazků nejen České republiky, ale i samotných obcí jsou potřeba informace, které lze mimo jiné získat i analýzami složení a kvality komunálních odpadů. K tomu Ize využít analýz a výše uvedených metodik at už pro porovnání s jinými obcemi a využití jejich zkušeností, nebo pro vyhodnocení vlastních specifických projektů. S obojím je tým VúV TGM príipraven obcím pomoci.

\section{Poděkování}

Príspěvek byl podpořen z institucionálních prostředkü na rozvoj výzkumné organizace VÚV TGM v rámci interního grantu č. U4802/2021.

\section{Literatura}

[1] INFO@AION.CZ, A. C. 128/2000 Sb. Zákon o obcích. Zákony pro lidi [on-line]. [vid. 30. červen 2021]. Dostupné z: https://www.zakonyprolidi.cz/cs/2000-128

[2] OODP-MM_Min_vnitra_Pravni_vyklad_Obecni_system-15122020.pdf [on-line]. [vid. 25. červen 2021]. Dostupné z: https://www.mzp.cz/C1257458002F0DC7/cz/stanoveni_obecneho_systemu_ odpadoveho_hospodarstvi/\$FILE/OODP-MM_Min_vnitra_Pravni_vyklad_Obecni_system15122020.pdf

[3] OODP-MM_Min_vnitra_Vzor_OZV_Obecni_system-15122020.pdf [on-line]. [vid. 25. červen 2021]. Dostupnéz: https://www.mzp.cz/C1257458002F0DC7/cz/stanoveni_obecneho_systemu_odpadoveho_hospodarstvi/ \$FILE/OODP-MM_Min_vnitra_Vzor_OZV_Obecni_system-15122020.pdf

[4] OODP-MM_Min_vnitra_Zmocneni_k_vydani_OZV-15122020.pdf [on-line]. [vid. 25. červen 2021]. Dostupnéz: https://www.mzp.cz/C1257458002F0DC7/cz/stanoveni_obecneho systemu_odpadoveho hospodarstyi/ \$FILE/OODP-MM_Min_vnitra_Zmocneni_k_vydani_OZV-15122020.pdf

[5] SW-TOOL CONSORTIUM. Methodology for the Analysis of Solid Waste (SWA-Tool) [on-line]. B. m. European Commission. Březen 2004. Dostupné z: https://www.wien.gv.at/meu/fdb/pdf/swa-tool759-ma48.pdf

[6] WAVRER, P. Theory of Sampling (TOS) applied to characterisation of Municipal Solid Waste (MSW)-a case study from France. TOS forum [on-line], nedatováno, roč. 2018, č. 8, s. 3-11. Dostupné z: doi:10.1255/tosf.101

[7] Merkblatt für die Durchführung von Untersuchungen zur stofflichen Zusammensetzung des Restmülls aus Haushaltungen [on-line]. 15. leden 2013. Dostupné z: https://tlubn.thueringen.de/fileadmin/ umweltschutz/Abfall/Landesabfallwirtschaftsplanung/hma-merkblatt_01_15_2013.pdf

[8] CORNELISSEN, A. A. J., OTTE P. F. Physical investigation of the composition of household waste in the Netherlands. B. m.: National Institute of Public Health and Environmental Protection Amersfoort Březen 1995

[9] Nordtest Method-Finland, nedatováno, s. 1-12. ISSN 0238-445.

[10] RYLANDER, H. Manual for plockanylys av hushallsavfall. B. m.: RVF Utveckling 2005:19

[11] FOEN, F. O. for the E. A survey of the composition of household waste 2001/02 [on-line]. [vid. 7. červenec 2021]. Dostupné z: https://www.bafu.admin.ch/bafu/en/home/themen/thema-abfall/abfall-publikationen/publikationen-abfall/erhebung-der-kehricht-zusammensetzung-2001-02.htm

[12] BURNLEY, S. J., ELLIS, J. C., FLOWERDEW, R., POLL, A. J., PROSSER, H. Assessing the composition of municipal solid waste in Wales. Resources, Conservation and Recycling [on-line]. 2007, roč. 49, č. 3 , s. 264-283. ISSN 0921-3449. Dostupné z: doi:10.1016/j.resconrec.2006.03.015

[13] BENEŠOVÁ, L., ČERNíK, B., HNAT̈UKOVÁ, P., KOTOULOVÁ, Z., VRBOVÁ, M. Výzkum vlastností komunálních odpadů a optimalizacejejich využívání [on-line]. Zpráva pro závěrečný kontrolní den. B. m. Univerzita Karlova v Praze, Prírodovědecká fakulta. 2008. Dostupné z: http://www.komunalniodpad. eu/download/Prubezna_zprava_-odpady__2008_web.pdf

[14] Rozbory směsných komunálních odpadů | Odpadová poradenská [on-line]. [vid. 2. leden 2021]. Dostupné z: https://www.odpadovaporadenska.cz/pro-obce/rozbory-sko/

[15] HRABINA, D. Metodika analýz komunálních odpadů. In: Odpady a obce 2017: Odpady a obce 2017 [on-line]. 2017, s. 57-58. Dostupné z: https://www.ekokom.cz/uploads/attachments/OD/ SBORN\%C3\%8DK\%2017_20170619.pdf

[16] VOLOŠINOVÁ, D., KOŘíNEK, R., MAKOVCOVÁ, M. Monitoring odpadové obslužnosti pro tříděné složky komunálního odpadu na území hlavního města Prahy. Vodohospodárské technicko-ekonomické informace. 2019, roč. 61, č. 6, s. 40-46. ISSN 0322-8916, 1805-6555.

\section{Autoři}

Ing. Dagmar Vološinová

$凶$ dagmar.volosinova@vuv.cz

ORCID: 0000-0003-1195-7046

Ing. Robert Kořínek, Ph.D.

凶robert.korinek@vuv.cz

ORCID: 0000-0001-5849-5606

Ing. Jiří Kučera

凶jiri.kucera@vuv.cz

ORCID: 0000-0002-7540-4750

Výzkumný ústav vodohospodářský T. G. Masaryka

Príspěvek prošel lektorským řízením.

DOI: 10.46555/VTEI.2021.07.004

\section{MUNICIPAL WASTE MANAGEMENT IN THE LIGHT OF NEW REGULATIONS}

\section{VOLOSINOVA, D.; KORINEK, R.; KUCERA, J.}

T. G. Masaryk Water Research Institute

Keywords: waste - municipal waste - disposal legislation - circular economy

Modern municipal services in solid waste management usually include cleaning and cleaning of public spaces, collection, transport, recycling and disposal of generated waste. Solid waste management services are among the most expensive and complicated municipal work systems for the public. At the same time, it can also be the least awarded communal service. Water, electricity, firefighting and police protection meet the daily needs of residents and businesses fundamentally and immediately. Therefore these services are given a much higher priority by the community and its leadership. Waste management services are usually one of the most minor "fragrant" public services, but their flawless functionality and efficiency have far-reaching implications. The legislation serves to ensure the sustainability and uniformity of the waste management process. Regulations governing the waste management of municipalities in the Czech Republic have been updated for a long time this year, and to date (1 July 2021) Act No. 541/2020 Coll., On waste and Decree No. 8/2021 Coll., The Catalog of wastes, are effective. The second implementing regulation, the Decree on Waste Management, is currently in the Government's Legislative Council. Its release is expected during July. The following article describes what changes these regulations bring for municipal waste management and how to prepare for them. 